\title{
IS/IT CAPABILITY AND STRATEGIC INFORMATION SYSTEM PLANNING (SISP) SUCCESS
}

\author{
Naser Khani ${ }^{*}$, Khalil Md Nor $^{2}$, Hossein Hakimpoor ${ }^{3}$, Mojgan Bahrami ${ }^{4}$, Shahram \\ Salavati $^{5}$ \\ ${ }^{1}$ Islamic Azad University, Najafabad Branch, Iran. \\ Ph.D. student at Universiti Teknologi Malaysia, Johor, Skudai, Malaysia \\ * E-mail: khani 451@yahoo.com (corresponding author) \\ ${ }^{2}$ Universiti Teknologi Malaysia, Johor, Skudai, Malaysia (UTM) \\ kmdnor afppsm . utm.my \\ ${ }^{3}$ Islamic Azad University, Birjand Branch, Iran, Ph.D. student at UTM \\ hhakimpuregmail.com \\ ${ }^{4}$ Islamic Azad University, Mobarakeh Branch, Iran, Ph.D. student at UTM \\ Samani_518@yahoo.com.sg \\ ${ }^{5}$ Islamic Azad University, Tonekabon Branch, Iran \\ salavatishegmail.com
}

\begin{abstract}
Successful planning of Information Systems (SISP) is perhaps going to be more problematic in today's world of rapid change and uncertainty. SISP is a cornerstone of the information system discipline and very little attention has been paid to its success based on the resource based view of the firm (RBV).This paper provides a model for IT capability and strategic information system planning success, by considering environmental and organizational factors that may influence this relationship in a contingency model. A review of existing IT capability and SISP literature is given to identify the opportunities in building successful SISP. A model is developed by hypothesizing IT capability as independent variable leads to SISP success as dependent variable; in which organizational \& environmental influences are considered as moderating variables. The control variables are firm size, firm structure, and industry type. The study proposes a model to conceptualize the relationship between IT capabilities and SISP success and contingency factors moderating that relationship. This paper explains the ways of exploiting IT capabilities as specialized and integrated knowledge of the firm in IT area to create a more successful SISP. The researchers believe that the aim to build a model for SISP success based on RBV theory is important because this new perspective will be helpful for gaining a superior assessment and better underpinning of the SISP from a knowledge based perspective.
\end{abstract}

KEYWORDS: firm-wide IS capability, strategic information systems planning.

\section{INTRODUCTION}

As a new strategic perspective in IS management field, RBV proposes that it is possible to exploit human, technical, and business dimensions of information systems (IS capabilities). Through a capability perspective, this study will look for SISP success. Many studies have been done on 
International Journal of Managing Information Technology (IJMIT) Vol.3, No.3, August 2011

SISP or IS capabilities, but the relationship between IS capabilities and SISP success and moderating factors affecting this relationship have not been investigated yet.

IS success has been such an attractive research subject for many scholars and researchers; as IS and technology grow and environment becomes more competitive and strategies of the business change, SISP can help firms to encounter this complexity, analyze environment, track IT development, monitor how competitors use IT, plan more effective infrastructure and finally impact business objectives. In addition, strategic information system planning (as of now: SISP) has been interpreted as an important management issue. Some believe that SISP is the best framework for assuring that IS efforts are concordant with other organization's activities and arising needs [1]. According to Bechor et al [2], SISP "is the process of strategic thinking that identifies the most desirable IS on which the firm can implement and enforce its long-term IS activities and policies" (p: 1). Prior research on SISP success involves topics such as the effect of senior management approval [3], SISP critical success factors [4], [2] and various other aspects.

\section{IS CAPABILITY}

\subsection{IS and sustainable competitive advantage}

Recently, there is increasing interest in studying the "sustainability" essence to maintain the continuity of the advantages of IS/IT investments. Sustainability and competitive advantage have a clear distinction; while sustainability relates to an ongoing status, a specific competitive advantage might be temporary [5]. From an IS point of view, sustainability is the organization's ability to provide continues explicit value for business through IS/IT [6] .While IT investments still provide effectiveness and efficiency and also seek out competitive advantage opportunities through IT and IT-business strategy alignment, yet scant attention has been paid to the organizational mechanisms through which firms achieve sustained and repeated value from IT [7]. Therefore, the challenge of understanding how to develop this sustainability is becoming more important.

Some researchers ([5], [8], [9], [10], [11], [12], [13], [14]) have hinted to the IT and sustainable competitive advantage (CA). In summary, their studies show that when all firms have access to a similar technology, this is management differences that determines CA. Accordingly, acquiring sustained IT-based CA requires organizational infrastructure to provide innovative action strategies and needs IT management skills to contribute to utilizing intangibles, business and human resources. In essence, this is management differences that determines economic superiority that firms gain from their IS/IT investments. For example, some managers can fit the parts together more elaborately than others, so management IS/IT skills could be a source of sustainable competitive advantage. In this regard, researchers ([14], [15], [16]) have shown that in order to use IT to improve organization's ongoing competitiveness, "IS capability" has to be developed. Rooted in strategic management and RBV perspective, IS capability is the organization ability of IS/IT usage to continuously leverage and exploit business value [7].

\subsection{IS capability evolution}

RBV perspective has gained increasing dominance in the strategic management field and views organization as a bundle of resources. According to Barney the organizational resources are the main elements that differentiate an organization from others in the industry and make the firm 
International Journal of Managing Information Technology (IJMIT) Vol.3, No.3, August 2011

matchless. Barney has defined resources as information, knowledge, firm attributes, organizational processes, assets and capabilities that empower the firm to formulate and implement effective and efficient strategies [17].

In RBV perspective, IS capabilities are intrinsic part of the strategy instead of being strategy outcome. Using RBV perspective in strategic management thinking, the focus on the demand side has changed with emphasize on supply side that is associated with organizational capabilities.

IT resources are software, hardware, communication, IT personnel and IT applications which are hardly inimitable and unique and consequently cannot be a source of competitive advantage [18]. Instead, Mata et al. [5] have introduced IT attributes (i.e. managerial IT skills, technical IT skills, proprietary technology, access to capital and customer switching costs) and have argued that only managerial IT skills can provide distinct advantage. Then, Bharadwaj [14] showed that although IT resources have no innate value, a combination of IT resources and human and business resources, as complementary resources, can guarantee higher firm performance. Similar to Teo and Ranganathan [18], Peppard and Ward [7] introduce IS resources as business resources, technical (IT resources) and behavior and attitude (human part of IS resources) in their model (Figure 1).

Although many research have been conducted about IT capability notion, there is little consensus on its description ([19], [40]). According to Srinivasan et al. [20] definition, resource is a particular asset or know-how while the capability comprises of skills gained through firm's processes that empower organization to use its assets. Defining competence as a firm-wide concept that represents a group of technologies and skills, Peppard and Ward [7] discuss that the capability notion reflects the strategic application of those competencies in order to attain business objectives. Peppard and Ward [7] have explicitly used the organization's IT exploitation concept to provide a framework for positioning IS capability. Based on the Calderia [21] model, they also constructed a model to indicate the IS capability components [7]. Figure 1 indicates IS capability and its components.

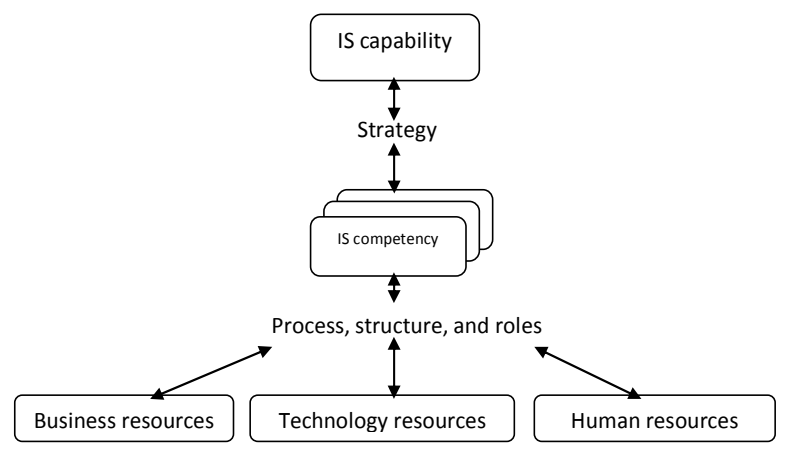

Figure 1: IS capability and its components (IS competencies) - Adapted from Peppard and Ward (2004)

In IS capability perspective, the fundamental promise is that, they are utilizing and combining mechanisms that produce the firm's strategic benefits; such mechanisms (e.g. like managerial IT skills) are firm specific and hard to imitate [18]. Peppard and Ward [7], suggest that these are firm's process, roles and structure that produce and shape those mechanisms. Accordingly, they 
International Journal of Managing Information Technology (IJMIT) Vol.3, No.3, August 2011

propose that IS capability has three attributes: business and IT knowledge fusion, flexible IT infrastructure, and effective utilization process.

\subsection{The position of IT capability among other organizational capabilities: a knowledge perspective}

The organizational capability theory is based upon the integration of specialized knowledge of organizations' members, in which efficiency of the knowledge acquisition needs individuals' specialization in a specific knowledge and knowledge application requires accumulation of several areas of expertise knowledge [22]. Knowledge application to production_ that is value creation through input into output transformation_ requires many specialized knowledge areas to be brought together [23] and shape organizational capability.

From an organizational perspective, organizational capabilities have been described as a hierarchy by Grant [22], where functional capabilities are the result of specialized capabilities' combination. Likewise, functional capabilities' integration forms a higher level of capabilities that are cross functional capabilities (figure 2). For example, new product development capability-as a cross functional capability derives from operations, $R \& D$ and design, and marketing and sales capabilities.

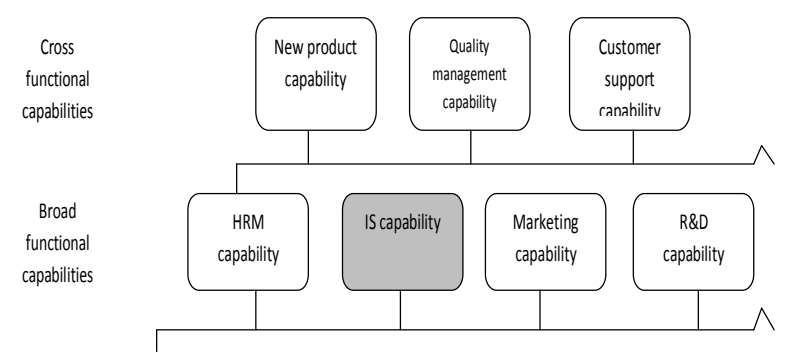

Figure 2: the hierarchy of capabilities and the position of IS capability

By considering knowledge as a single resource, Grant [22] has defined organizational capability as the ability of a firm to carry out a productive task repeatedly that influence a firm's aptness for value creation through input-process-output concept. The fundamental notion in this definition is knowledge. Specialists' knowledge integration to do a distinctive productive task is the essence of organization capabilities. For example, popular chain fast food's capability in serving special foods is an organization capability that requires specialized knowledge integration among too many employees [24].

Based on the role of organizations in acquisition, processing and implementing knowledge, individuals' expertise knowledge is the essence of organizational capability [22] that shapes other levels of organizational capabilities. Here, tacit knowledge, in the form of practical knowledge, know-how, and skills is related to production task. 
International Journal of Managing Information Technology (IJMIT) Vol.3, No.3, August 2011

\subsection{IS capability as the fourth IS era}

King [25] discussed that strategic capability architecture (SCA) is the fundamental basis for sustainable competitive advantage of a company. In his discussion SCA is a basic plan of organizational capability that is continuously improving and flexible. Consequently, by the application of RBV in IS management the notion of IS capabilities emerges that considers developing and leveraging business value through IS. As Peppard and Ward have proposed, this can be assumed as the forth era in IS management field.

IS management era has faced with several changes from 1960 to 2002. According to the model that Ward and Griffith [26] have developed, there were three different, albeit overlapping, IS management eras. Table 1 depicts a model of four eras of IS evolution [26], [6].

Table 1: The four IS eras

\begin{tabular}{|l|l|l|}
\hline Time & Era & Specifications \\
\hline 1960s & $\begin{array}{l}\text { Data processing } \\
\text { (DP) }\end{array}$ & $\begin{array}{l}\text { Single computers and cost } \\
\text { saving objectives }\end{array}$ \\
\hline $\begin{array}{l}\text { 1970s- } \\
\text { 1980s }\end{array}$ & $\begin{array}{l}\text { Management } \\
\text { information } \\
\text { systems (MIS) }\end{array}$ & $\begin{array}{l}\text { User-driven, interconnected, } \\
\text { process distributed }\end{array}$ \\
\hline $\begin{array}{l}\text { 1980s- } \\
1990 \text { s }\end{array}$ & $\begin{array}{l}\text { Strategic } \\
\text { information } \\
\text { systems (SIS) }\end{array}$ & $\begin{array}{l}\text { Business-driven, networked, } \\
\text { related to business strategy, } \\
\text { seeking out competitive } \\
\text { advantages through IT } \\
\text { opportunities }\end{array}$ \\
\hline 2000s & IS capability & $\begin{array}{l}\text { considers developing \& } \\
\text { leveraging business value } \\
\text { through IS }\end{array}$ \\
\hline & \begin{tabular}{l} 
Source: Adapted from [26], [6] \\
\hline
\end{tabular} \\
\hline
\end{tabular}

According to archival analyses of strategic information systems researches, three distinct category of research have been identified [27]: (1) IS for strategic decision making, (2) Strategic use of IS, and (3) Strategies for IS issues (i.e. IS management, IS planning, IS organization, IS development method, application service provision, IS implementation, IS evaluation, and IS adoption). In the third main topic, strategic IS planning has received the most researchers' attention after IS management subtitle and accordingly is the subject of focus in this paper.

\section{SISP SUCCESS}

SISP field has attracted many scholars and is continually identified as the most crucial issue facing by organizations from 1980s [28], [29]. Similar to other organizational activities, SISP must be defined properly. Segar and Grover [30] defined SISP as a complicated set of organizational actions that represent a philosophy not only a step by step planning method. SISP is concerned with the recognition of a set of IS applications and the required technology for strategic success of the organizations. Selection of the best methodology and choosing internal and external participants, budget establishment and goal defining are the main points of SISP focus [31]. 
International Journal of Managing Information Technology (IJMIT) Vol.3, No.3, August 2011

\subsection{SISP Evolution perspective}

SISP notion has experienced an evolution [32]. Rapid business and IT change have been recognized as the main drivers for SISP [33]. Those changes within recognition of IT as a strategic resource have caused SISP evolution. Figure 3 depicts the SISP evolution in four stages; each is the result of IT changing nature and its position as a strategic resource for the firms.

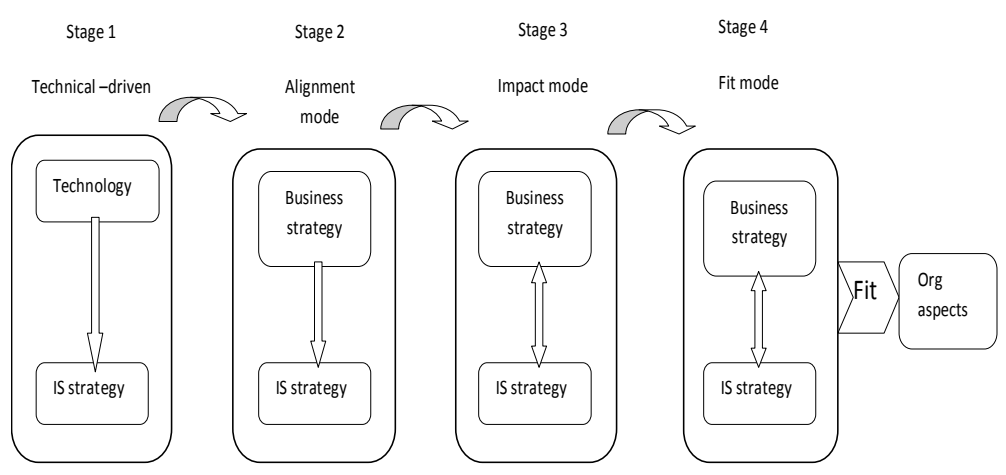

Figure3: the evolution perspective of SISP

\subsection{SISP success}

SISP requires significant amount of financial and human resources and considerable budget and managerial efforts [34] and is a crucial issue for IS and business managers and, furthermore, oftentimes is unsuccessful and hard to complete [35]. These issues have made it a legitimate goal for research. But such research could not be simply established on financial measures like return on investment (ROI) and other financial ratios; because like any other strategic planning it contains several intangible outcomes.

Among these four perspectives, goal-centered and improvement perspectives are more appropriate because SISP has an ongoing nature and a broad focus and involves different outcomes [34]. To fill this requirements, goal-centered approach represents planning outcomes as "ends" and improvement approach represents process adaptability as "means" of effectiveness assessments.

\subsubsection{SISP success dimensions}

Based on this fact that the effectiveness aspects in IS management field are complex [35], a collection of interdependent success dimensions can assess success more properly in contrast to a collection of financial measures or all items measurement. By keeping this in mind and with a broad literature review, Segar and Grover [34] have introduced four dimensions of alignment, cooperation, analysis, and capability improvement in which the first three are "goals" representatives and the last one measures SISP improvement over time. Some researchers have defined another dimension titled contribution [36]. These dimensions and their descriptions are indicated in table 2 . 
International Journal of Managing Information Technology (IJMIT) Vol.3, No.3, August 2011

Table 2: SISP success dimensions

\begin{tabular}{|l|l|}
\hline scale & explanation \\
\hline alignment & $\begin{array}{l}\text { IS and business strategy linkage to facilitate such IT/IS development and } \\
\text { acquisition that is concordant with competitive requirements of the organization }\end{array}$ \\
\hline analysis & $\begin{array}{l}\text { Understanding the organization's internal operations (e.g. procedures, processes, } \\
\text { and technologies) }\end{array}$ \\
\hline cooperation & $\begin{array}{l}\text { SISP stakeholders cooperation to decrease potential conflict between them after } \\
\text { general agreements }\end{array}$ \\
\hline $\begin{array}{l}\text { improvement } \\
\text { in capabilities }\end{array}$ & Improving planning capabilities over time (e.g. by learning) \\
\hline contribution & $\begin{array}{l}\text { contributing to various organizational attributes (e.g. decision making and } \\
\text { profitability) }\end{array}$ \\
\hline
\end{tabular}

Source: Adapted from: Segars and Grover [30]

\section{IS capabilities and SISP success integration}

Despite this fact that SISP is a cornerstone of the information system discipline [27], very little attention has been given to its success based on the resource- based view of the firm (RBV) in strategic management field. Generally, literature mirrors significantly little effort to recommend a framework for understanding the relationship between "IS capabilities" and "SISP success" in particular. To be clearer, the question is that what kind of skills and abilities, knowledge, and qualification or capacity is needed for organizations to have a successful planning of strategic information systems? And what conditions affect this relationship? To fill this gap in the IS field, this paper aims to establish a conceptual model by providing a contingency model to investigate this relationship. The researchers believe that the aim to build a model for SISP success based on RBV perspective is important because this new perspective will be helpful for gaining a superior assessment and better understanding of the SISP.

Additionally, if organizations understand the capabilities required for IS success, by developing and leveraging them, they can use their IS investment more competitive and more effective. But, the success of SISP cannot solely predicted from IS capabilities and there might be other factors that affect this relationship. SISP context comprises of variables that exhibit environmental and organizational attributes and outside conditions that may influence the process and consequently the success of SISP (e.g., organization's IT importance, organizational structure, and environmental uncertainty). Lederer and Salmela [35] have divided environment construct into two part of internal and external. Organization size, structure, and culture, managerial style, IS role and maturity and IS planning goals were among attributes of the internal environment. On the other side, the external environment included economic stability of the industry and country, business sector information intensity and changing in market forces and trends. Wade and Hulland [37], introduce external environment (that mostly refers to environmental uncertainty) and internal influences (organizational culture, and organizational structure) and top management support as main contextual factors in IS studies ([38], [39]) . Based on a contingency model, the abovementioned factors shaped the moderating factors of this study that are titled "organizational and environmental influences". Consequently, the research model is as follow that will be tested in an empirical research (figure 5). 


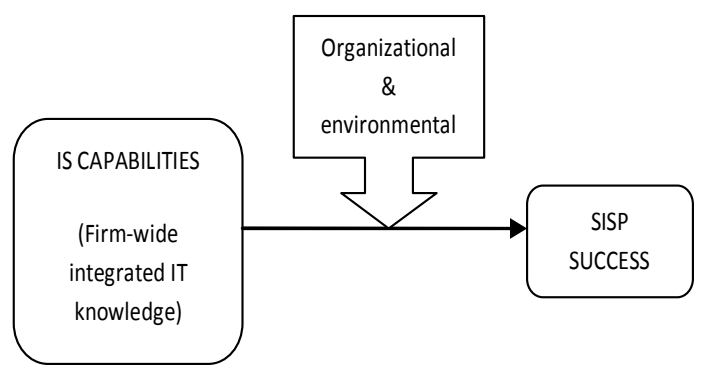

Figure 5: IS capabilities, SISP success, and moderating factors

\section{Conclusion}

Generally, capability has been interpreted to have the ability to influence organizational success. As an organizational construct, IS/IT capability is related to the ability of an organization to provide sustainable competitive advantage in IS field. IT capability is the ability to deliver system, control IT costs, and affect objectives of the business with IT implementation. Conceptualizing the relationship between IS capabilities and SISP success and factors moderating this relationship was the aim of this study. In this research through RBV perspective, this relationship has been investigated. Finally, Because of possible inconsistency between those two variables (IS capabilities and SISP success), factors moderating this relationship were introduced based on a contingency model to address planning paradox.

\section{Acknowledgment}

We would like to thank Universiti Technologi Malaysia (UTM), Ministry of Higher Education (MOHE), and also IAU (Najafabad, Birjand, Mobarakeh, and Tonekabon branches) for their continuous support.

\section{REFERENCES}

[1] SABHERWAL, R. \& CHAU, Y. E. 2001. Alignment between business and IS strategies: A study of prospectors, analysers and defenders. 12, 11-33.

[2] BECHOR, T., NEUMANN, S., ZUIRAN, M. \& GLEZER, C. 2010. A contingency model for estimating success of strategic information systems planning. Information \& Management, 47, 17-29.

[3] KEARNS, G. S. 2006. The effect of top management support of SISP on strategic IS management: insights from the US electric power industry. Omega 34, 236-253.

[4] BASU, V., HARTONO, E., LEDERER, A. L. \& SETHI, V. 2002. The impact of organizational commitment, senior management involvement, and team involvement on strategic information systems planning. Information \& Management, 39, 513-524.

[5] MATA, F. J., FUERST, W. L. \& BARNEY, J. B. 1995. Information technology and sustained competitive advantage: a resource-based analysis. MIS Quarterly, 487-505.

[6] WARD, J. \& PEPPARD, J. 2002. strategic planning for information systems, Cranfield, Bedfordshire, UK, Cranfield School of management. 
International Journal of Managing Information Technology (IJMIT) Vol.3, No.3, August 2011

[7] PEPPARD, J. \& WARD, J. 2004. Beyond strategic information systems: Towards an IS capability. Journal of Strategic Information Systems, 167-194.

[8] KEEN, P. G. W. 1993. Information technology and the management difference: A fusion map. IBM Systems Journal, 32, 17-39.

[9] KETTINGER,W., GROVER, V., GUHA, S. \& SEGARS, A. H. 1994. Strategic information systems revisited: A study in sustainability and performance. MIS Quarterly, 18, 31-55.

[10] CIBORRA, C. 1994. Toward a Fourth Era: An Organizational IS Capability 55 grassroots of IT and strategy. In: CIBORRA, C. \& JELESSI, T. (eds.) Strategic Information Systems: A European Perspective. Chichester, UK John Wiley \& Sons.

[11] POWELL, T. C. \& DENT-MICALLEF, A. 1997. Information technology as competitive advantage: The role of human, business and technology resources. Strategic Management Journal, 18, 375-405.

[12] DVORAK, R. E., HOLEN, E., MARK, D. \& MEEHA, W. F. 1997. Six principles of highperformance IT'. The McKinsey Quarterly, 3, 164-177.

[13] MARCHAND, D. A., KETTINGER, W. \& ROLLINS, J. D. 2000. Information orientation: People, technology and bottom line. Sloan management review, Summer, 69-80.

[14] BHARADWAJ, A. S. 2000. 'A resource-based perspective on information technology and firm performance: An empirical investigation'. MIS Quarterly, 24, 169-196.

[15] BHARADWAJ, A. S., SAMBAMURTHY, V. \& ZMUD, R. W. 1999. IT capabilities: Theoretical perspectives and empirical operationalization. 20th International Conference on Information Systems. Atlanta,USA.

[16] ROSS, J. W., BEATH, C. M. \& GOODHUE, D. L. 1996. Develop long-term competitiveness through IT assets. Sloan Management Review, 38, 31-42.

[17] BARNEY, J. 1991. Firm resources and sustainable competitive advantage. Journal of Management Decision, 17, 99-120.

[18] TEO, T. S. H. \& RANGANATHAN, C. 2003. Leveraging IT resources and capabilities at the housing and development board. Journal of Strategic Information Systems, 12, 229-249.

[19 ] CALDEIRA, M. \& DHILLON, G. 2010. Are we really competent? Assessing organizational ability in delivering IT benefits. Business Process Management Journal, 16, 5-28.

[20] SRINIVASAN, R., LILIEN, G. \& RANGASWARNY, A. 2002. Technological Opportunism and Radical Technology Adoption: An Application to E-Business. Journal of Marketing, 66, 47-60.

[21] CALDEIRA, M. 1998. Understanding the Adoption and Use of Information Systems/Information Technology in Small and Medium-Sized Manufacturing Enterprises: A Study in Portuguese Industry,Unpublished $\mathrm{PhD}$ Thesis. Cranfield School of Management.

[22] GRANT, R. M. 1996. Prospering in Dynamically-Competitive Environments: Organizational Capability as Knowledge Integration. Organization Science, 7, 375-387.

[23] DEMSETZ, H. 1991. The Theory of the Firm Revisited. In: WILLIAMSON, E. \& WINTER, S. (eds.) The Nature of the Firm,. New York: Oxford University Press.

[24] YONGMEI, L., HONGJIAN, L. \& JUNHUA, H. 2008. IT Capability as Moderator Between IT Investment and Firm Performance. Tsinghua Science and Technology, 13, 329-336.

[25] KING, W. 1995. Creating A Strategic Capabilities Architecture. Information Systems Management 12.

[26] WARD, J. \& GRIFFITH, P. 1996. Strategic Planning For Information Systems (2nd Edition). John Wiley \& Son, London.

[27] GABLE, G. 2010. Strategic information systems research: An archival analysis. Journal of Strategic Information Systems, 19, 3-16.

[28] FEENY, D. F., EDWARDS, B. \& AL., E. 1992. Understanding the CEO/CIO relationship. MIS Quarterly 16, 435-449.

[29] WATSON, R., KELLY, G., GALLIERS, R. D. \& BRANCHEAU, J. 1997. Key issues in information systems management: An international perspective. Journal of Management Information Systems, 13, 91-115.

[30] SEGARS, A. H. \& GROVER, V. 1999. Profiles of strategic information system planning. information systems research, 10, 199-232. 
International Journal of Managing Information Technology (IJMIT) Vol.3, No.3, August 2011

[31] HISHAM, B. M. B. \& MOHD , D. N. 2009. The Effect of Strategic Alignment on Strategic Information System Planning (SISP) Success: An Exploratory Study in Public Universities in Malaysia. International Journal of Scientific Research in Education, 2, 76-87.

[32] LEDERER, A. L. \& SETHI, V. 1988. The implementation of strategic information systrem planning methodologies. MIS Quarterly, 12, 445-461.

[33] NEWKIRK, H. E., LEDERER, A. L. \& JOHNSON, A. M. 2008. Rapid business and IT change: drivers for strategic information systems planning? European Journal of Information Systems, 17, 198-218.

[34] SEGARS, A. H. \& GROVER, V. 1998. Strategic Information Systems Planning Success: An Investigation of the Construct and Its Measurement. MIS Quarterly, 22, 139-163.

[35] LEDERER, A. L. \& SALMELA, H. 1996. Toward a theory of strategic information systems planning. Journal of Strategic Information Systems, 5, 237-253.

[35] DELONE, W. H. \& MCLEAN, E. R. 1992. Information systems success: the quest for the dependent variable. Information Systems Research, 3, 60-95.

[36] DOHERTY, N. F., MARPLES, C. G. \& SUHAIMI, A. 1999. The relative success of alternative approaches to strategic information systems planning: an empirical analysis. Journal of Strategic Information Systems, 8, 263-283.

[37] WADE, M. \& HULLAND, J. 2004. Review: The Resource-Based View and Information Systems Research: Review, Extension, and Suggestions for Future Research. MIS Quarterly, 28, 107-142.

[38] Khani, N., Md Nor, K., and Bahrami, M. (2010), Factors Moderating the Relationship between IS Capabilities and Strategic Information System Planning (SISP) Success, 3 rd International Graduate Conference on Engineering, Science, and Humanities 2010 (IGCESH2010), 2nd-4th November 2010, UTM, Johor.

[39] Khani, N., Md Nor, K., and Bahrami, M. (2011), A Proposed Research Model for the Relationship between Organizational IS capabilities, Organizational Performance and Strategic Planning, 16th IBIMA Conference (Innovation and Knowledge Management: A Global Competitive Advantage), Kuala Lumpur, Malaysia 29-30 June 2011.

[40] Jorfi, S., Md Nor, K., and Najjar, L., (2011), the relationships between IT flexibility, IT-business strategic alignment, and IT capability, International Journal of Managing Information Technology (IJMIT) Vol.3, No.1, February 2011. 